
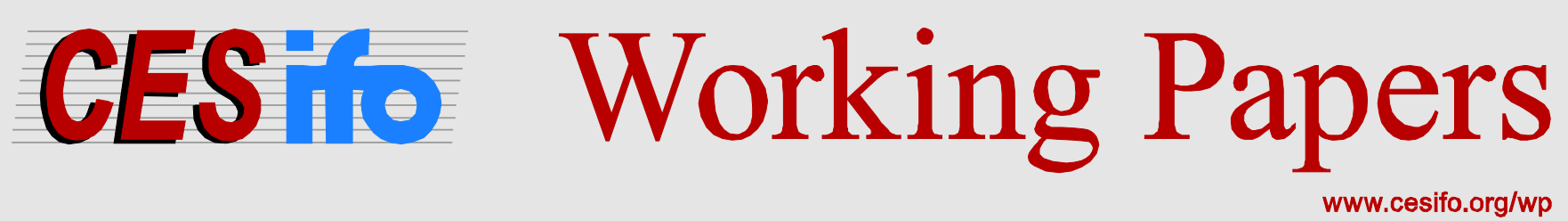

\title{
Depressing Dependence? Transfers and Economic Growth in the German States, 1975-2005
}

\author{
Thushyanthan Baskaran \\ Lars P. Feld \\ Sarah Necker
}

CESIFO WORKING PAPER NO. 6055

CATEGORY 1: PUBLIC FinANCE

August 2016
An electronic version of the paper may be downloaded
- from the SSRN website:
- from the RePEc website:
- from the CESifo website:
wWw.SSRN.com
Www.RePEc.org
www.CESifo-group.org/wp

\section{CESifo}




\title{
Depressing Dependence? Transfers and Economic Growth in the German States, 1975-2005
}

\begin{abstract}
Most countries pay substantial intergovernmental transfers to poor regions. Since these transfers are often paid with the aim of achieving regional convergence, they should have a positive effect on economic growth. However, it is equally possible that transfers perpetuate underdevelopment by diminishing regional incentives to implement growth-enhancing policies. In this paper, we study empirically the effect of intergovernmental transfers on economic growth using the German federation as an institutional laboratory. Our findings, which are based on a panel dataset covering the West German States over the period 1975-2005, suggest that transfers are irrelevant or possibly even harmful for economic growth. The results of our analysis of transmission channels are consistent with the notion that transfers fail to foster growth because states use them to subsidize declining industries.
\end{abstract}

JEL-Codes: H700, H730, H770.

Keywords: intergovernmental transfers, economic growth, fiscal federalism.

\author{
Thushyanthan Baskaran \\ University of Siegen \\ Siegen / Germany \\ baskaran@vwl.uni-siegen.de
}

\author{
Lars P. Feld* \\ University of Freiburg \& \\ Walter Eucken Institute \\ Freiburg / Germany \\ feld@eucken.de
}

\author{
Sarah Necker \\ University of Freiburg \& \\ Walter Eucken Institute \\ Freiburg / Germany \\ sarah.necker@vwl.uni-freiburg.de
}

*corresponding author

We would like to thank Bodo Aretz (German Council of Economic Experts, Wiesbaden) for providing us with the $2 \%$ sample of the Integrated Employment Biographies (SIAB) and participants of the Annual Meeting of the European Public Choice Society, 28. April 1. Mai 2011 in Rennes/France for their comments. 


\section{Introduction}

Most countries redistribute public resources between regions through intergovernmental transfers. Such transfers tend to be controversial if the net-paying regions have to subsidize the recipients for long periods. Discontent in the net-paying regions may lead to growing support for separatist movements and facilitate political disintegration. In Northern-Italy, for example, the persistent transfers to the Mezzogiorno have caused the rise of secessionist regional parties. In Spain, the rich Catalan and Basque regions are famous for their desire to break away from the rest of the country. In Belgium, regionalist Flemish parties complain about having to bankroll the Walloon region. In Scotland, disagreement between the division of fiscal resources and the extent of fiscal autonomy lay at the heart of the recent independence referendum.

Yet, there are reasons why countries might want to subsidize selected regions through intergovernmental transfers even if these transfers exacerbate political tensions. An important reason is that transfers can promote regional economic growth. Subnational jurisdictions can invest transfer receipts to expand regional infrastructure, foster structural change, and attract innovative firms 11 In line with convergence theories, it might be a sensible policy to allocate resources to poorer regions if they have a higher potential for growth (Barro and Sala-I-Martin, 1991). Alternatively, divergence theories indicate that without transfers, regions that are poor today will remain poor forever because rich regions have an agglomeration advantage (Boldrin and Canova, 2001).

In view of such arguments, most countries provide considerable resources to poor regions through intergovernmental transfer systems. The question, however, is whether poor regions really use transfers to generate growth. Higher growth rates and thus rising own-source revenues are likely to result in lower transfer receipts in the future. This implicit tax on the raising of own-source revenues diminishes incentives to invest transfers

\footnotetext{
${ }^{1}$ The literature has also developed more subtle arguments in favor of transfer programs. For example, transfer schemes represent an implicit insurance against fiscal shocks that hit regions asymmetrically (Bucovetsky, 1998, Persson and Tabellini, 1996b). Empirical evidence on this issue for Germany is provided by Büttner (2002). Related papers that explore the efficiency properties of intergovernmental transfer schemes are Persson and Tabellini (1996a) and Bucovetsky and Smart (2006).
} 
in growth-generating projects. Therefore, poor regions might prefer to spend transfers for consumptive purposes or to subsidize declining industries (Kessler et al., 2011).

Anecdotal evidence indicates that transfers indeed diminish rather than foster growth in transfer-dependent regions. A notable example is the Italian Mezziogiorno, which has remained poor despite receiving large transfers from the North for decades. The Italian case is so famous that the name Mezziogiorno is often used as the descriptive term for a region that is perpetually dependent despite receiving considerable transfers. Other countries appear to have their own Mezziogiornos: Belgium, for example, has the Walloon region and Germany has the East.

However, it is difficult to link transfers causally to low levels of growth based on anecdotal evidence because it is unclear whether economic development in transfer-dependent regions would have been even worse without the transfers. In this paper, we study econometrically how transfer dependence affects economic development with a dataset covering the 10 West German states over the period 1975-2005.2 More specifically, we explore the effect of transfers on economic growth and potential transmission channels such as retarded structural change and distortions in state fiscal policies.

Germany is a compelling laboratory to investigate the effect of transfer dependence on economic development since its Länderfinanzausgleich (state equalization system, LFA) redistributes every year considerable resources between the states. Through the LFA, states that have below-average tax revenues receive transfers both from states that have above-average tax revenues and from the federal government. In 2011, around 20 billion Euros were redistributed within this equalization scheme. Gross state revenues in 2011 were 286 billion Euros. Transfers thus constituted on average around 7\% of gross state revenues. For some net-recipient states, however, the LFA-transfers represent more than 30 percent of total revenues in some years.

\footnotetext{
${ }^{2}$ Even though data for the post-2005 period is available, another reform in 2005 changed transfer allocations. This reform was endogenous to previous transfer allocations as it was enforced by the federal constitutional court following a complaint of the net-payers in the equalization scheme.
} 
An important econometric challenge in establishing the causal effect of transfer dependence on economic development is the endogeneity of transfer receipts. Reverse causality is unlikely. Transfers are distributed according to a pre-determined law and therefore rule-based. By construction, expected future growth rates cannot determine transfer allocations in a given year. However, a concern is an omitted variable bias. The LFAsystem is constructed such that lower own-source revenues in a given year automatically induce higher transfers. Therefore, it is difficult to separately identify the growth effects of higher transfers from those of lower own-source revenues. In addition, further variables might exist that are correlated with both transfer receipts and economic development.

We address omitted variable bias through an instrumental variables approach. We construct an instrument based on an arguably exogenous reform of the intergovernmental transfer scheme in 1995 that increased the intensity of equalization and led to higher transfer dependence in the net-recipient states. This reform was necessitated by the need to integrate the East German States into the transfer system, but the changes in the equalization law affected all states. As German reunification was an unexpected shock ${ }^{3}$, it offers a compelling source of exogenous variation in transfer allocations.

This paper contributes to the literature on the link between intergovernmental transfers and economic development. The existing literature is inconclusive. A few studies explore the effects of various aspects of Germany's system of fiscal federalism, including those of the LFA-transfer scheme, on economic development (Berthold et al., 2001; Behnisch et al., 2002, Berthold and Fricke, 2005, 2007; Feld et al., 2012; Koetter and Wedow, 2013). However, the methodologies employed in these studies either suffer from endogeneity problems or rely on time series properties for identification.

While more credible evidence is available for other countries, the literature is mostly confined to developing and transition economies. Brollo et al. (2010) find that transfers enable corruption in Brazil. Reinikka and Svensson (2004) show that central transfers are

\footnotetext{
${ }^{3}$ Several previous contributions have used German reunification as a natural experiment to study various research questions, e. g., Fuchs-Schündeln and Schündeln (2005), Fuchs-Schündeln (2008), and Burchardi and Hassan (2013).
} 
wasted at the local level in Uganda. In contrast, several studies find that transfers lead to higher growth. Examples are Litschig (2012) for Brazilian municipalities and Becker et al. (2010, 2012) for structural funds paid by the EU to member states. However, the latter results are challenged by Breidenbach et al. (2016). The paper is also related to the literature on the effect of development aid and other resource windfalls on economic progress. Recent studies are, e.g., Burnside and Dollar (2000), Easterly (2003), Clemens et al. (2011), and Caselli and Michaels (2013). Finally, this paper contributes to the research on the link between fiscal decentralization and economic growth (Xie et al. 1999; Stansel, 2005; Thornton, 2007; Baskaran and Feld, 2013; Asatryan and Feld, 2015; Baskaran et al., 2016).

\section{Institutional details}

Germany has three tiers of government: the federal government (Bund), state governments (Länder), and the municipalities (Gemeinden). These three tiers of government are intertwined in a multitude of political and fiscal relationships. The federal and state governments, in particular, share responsibilities for several policy areas. At the core of the intergovernmental relations in Germany lies the sharing of tax revenues between the federal and state governments. Important taxes such as the personal and corporate income taxes as well as value-added taxes (VAT) are part of a tax sharing arrangement. These cover about three quarters of gross state (and federal) revenues.

Even though they receive significant parts of the proceeds, individual states have no authority to determine rates or bases for the shared taxes. Rates and bases for these taxes are decided at the federal level in negotiations between all states and the federal government and are the same throughout the federation. Changing rates or bases for the shared taxes therefore requires the consent of the majority of states and the federal government. The role of the states with respect to the shared taxes is effectively to assess and collect the revenues according to federation-wide regulations. 
Once revenues are collected, they have to be shared between all states. Tax sharing is executed through a system of implicit and explicit intergovernmental transfers, the Länderfinanzausgleich (fiscal equalization scheme). The professed goal of the intergovernmental transfers is to establish "a reasonable equalization of the disparate financial capacities of the Länder" (Art. 107 (2) of the Basic Law) and achieve comparable living conditions between the states by redistributing tax revenues from rich to poor states.

The general structure of the tax sharing scheme has largely remained the same during the period under study, i.e., 1975-2005. However, specific features - in particular marginal compensation and skimming rates of state tax revenues - were regularly changed. As described in more detail below, the most decisive changes took place in 1995. The following numbers regarding the tax sharing scheme are based on the 1995-2005 period.

The revenue sharing scheme is divided into four stages. On the first stage, revenues from shared taxes are distributed vertically among the three tiers of government (federal, state, and local). The federal and the state tier each receive 42.5 percent of gross revenues from the income tax, while the municipalities receive 15 percent. Corporate income tax revenues are shared equally between the federal and the state tier. While the shares for distributing revenues from income and corporate taxes are fixed by constitutional law, shares for distributing VAT revenues fluctuate over time (currently, the federal government receives 53 percent, the states 45 percent and the local tier 2 percent).

On the second stage, revenues from the shared taxes are distributed horizontally (i. e., between the states) according to the principle of local revenue accrual. Every state receives the state share of the revenues that it collects within its boundaries. An exception is the distribution of VAT revenues which contains a redistributive element. One quarter of those revenues is used to assure that every state receives at least $92 \%$ (90\% since 2005) of the average per capita tax revenues (Umsatzsteuervorwegausgleich). Despite this equalizing element, available state tax revenues after this stage of the tax sharing scheme can be described as own-source tax revenues. 
In a third step, intergovernmental transfers flow from fiscally well-endowed to poorlyendowed states. This stage of the equalization scheme is typically referred to as "narrow horizontal equalization" (LFA im engeren Sinn) since only the states are involved. The actual amounts to be paid or received by each state are determined by comparing a state's fiscal capacity to its fiscal needs, as defined by federal law. In general, fiscal capacity reflects a state's total tax revenues per capita after the first stage of tax sharing (i. e., their own-source revenues). However, some adjustments are made to account for municipal tax revenues and some other (minor) additional revenues. Fiscal needs are defined as roughly equal to the federation-wide average tax revenues per capita in a given year, but there are once more several adjustments. For example, the population figures on whose basis tax revenues per capita are calculated are scaled up for very densely (i. e., the city-states) or very sparsely populated states (i. e., some East-German states).

The difference between a state's fiscal capacity and fiscal needs determines for each state a marginal contribution/skimming rate. States that have higher fiscal capacity than fiscal needs must pay a certain fraction (determined by a piece-wise function of the difference) of their tax revenues into the equalization scheme. They are typically referred to as net-payers. States with lower fiscal capacity than needs receive transfers from the equalization scheme. These states are typically referred to as net-recipients.

In the fourth step, the federal government provides several grants to selected states (vertical equalization or Bundesergänzungszuweisungen). First, states whose fiscal capacity remains below $99.5 \%$ (97.5\% since 2005$)$ of the average fiscal capacity receive supplementary federal grants that close the gap (Fehlbetrags-Bundesergänzungszuweisungen). By construction, only net-recipient states receive these vertical transfers.

Second, some net-recipient states receive further federal transfers for specific reasons (Sonderbedarfs-Bundesergänzungszuweisungen). For example, the East-German states receive additional federal transfers that are supposed to help them overcome the costs of reunification. However, the transfers are paid without specific conditions and are therefore effectively indistinguishable from regular federal transfers. 
Given that our identification strategy relies on the allocation formula, we add to the verbal description of the equalization scheme a more formal one. With some omission of details, gross transfer receipts $T_{i t}$ of state $i$ in year $t$ can be decomposed as follows:

$$
T_{i, t}=H_{i, t}+V_{i, t}
$$

where $H_{i, t}$ are the transfers received or paid in the horizontal equalization stage (negative for net-paying states; positive for net-recipient states) and $V_{i, t}$ are the transfers received from the federal government (zero for net-paying states; positive for net-recipient states).

The gross horizontal transfers can be decomposed further as follows:

$$
H_{i, t}=h_{t} \underbrace{\left(Y_{i, t} / P_{i, t}-\left(\overline{Y_{t} / P_{t}}\right)\right)}_{x}
$$

where $Y_{i, t}$ are the own-source revenues of state $i$ in year $t$ and $P_{i, t}$ the (adjusted) population size. $\left(\overline{Y_{t} / P_{t}}\right)$ denotes the federation-wide average own-source revenues per capita ratio (based again on adjusted population figures), and $Y_{t}$ are the federation-wide gross revenues in year $t$. Finally, $h_{t}$ is a decreasing function (i. e., $h_{t}^{\prime}(x)<0$ ) that maps for each year into gross horizontal transfer payments or receipts the difference in own-source revenues per capita in state $i$ to the federation-wide average own-source revenues to GDP ratio. This difference is denoted with $x$. According to this function, gross horizontal transfers can increase if (i) either the function $h(\cdot)$ is adjusted such that a given level of $x$ leads to higher transfers or (ii) if $x$ decreases for some exogenous reason.

Gross vertical transfers can be decomposed as follows:

$$
V_{i}=v_{t} \underbrace{\left(Y_{i, t} / P_{i, t}+H_{i, t}-\left(\overline{Y_{t} / P_{t}}\right)\right)}_{z}+S_{i, t},
$$

where $v_{t}$ is a decreasing function (i. e., $v_{t}^{\prime}(z)<0$ ) of the difference between the sum of ownsource revenues and horizontal transfer receipts and average own-source revenues in the 
federation. Second, $S_{i, t}$ denotes the special vertical transfers that are paid independent of the difference between a given state's and average own-source revenues. It is easy to see from this expression that a net-recipient state $i$ receives higher transfers if (i) either the function $v_{i}$ is adjusted appropriately, (ii) if $S_{i, t}$ increases, or (iii) if the population size of the other states rises at a given population size of state $i$.

Figure 1 depicts the importance of the total intergovernmental transfers - i. e., the sum of the total horizontal and vertical transfers paid in a given year across all states included in the transfer system (this is equal to the transfers received) divided by the sum of revenues across these states $4^{4}$ This ratio reflects the relative importance of intergovernmental transfers in German fiscal federalism $5^{5}$ From the beginning of the sample period until 1995, the total transfers to total revenue ratio was slightly below $2 \%$. As indicated above, the transfer scheme was hit by two shocks around 1995. First, the East-German States were formally integrated into the transfer scheme. Second, the transfer scheme as a whole was reformed. The most important features of the reform included an increase in the share of the value added taxes that accrues to the states (from $37 \%$ to $44 \%$ ), the introduction of specific vertical grants that close the gap between fiscal capacity and fiscal needs up to $99.5 \%$ (see above), and special vertical grants to the states (see again above). The reforms in 1995 led to a substantial increase in the importance of intergovernmental transfers for state budgets. The average transfer ratio increased to around 6 percent and remained at this level until the end of the sample period.

\footnotetext{
${ }^{4}$ This ratio implicitly weights the transfer ratio by population size (as larger states pay/receive more transfers and have larger revenues ceteris paribus). Recall that there were only 10 states in the transfer system before 1995. After 1995, all 16 states were part of the system.

${ }^{5}$ We report how the sum of transfers across all states evolves in this figure even though we focus only on the West German states below in the regressions. The reason is that West German states pay the horizontal and (implicitly) the vertical transfers. Thus, West German (net-paying) states are affected by any transfers that flow to the East. It should be noted that the pattern of figure 1 is largely unchanged if we restrict the figure to West German states. Available upon request.
} 


\section{Construction of the panel}

To study the effect of intergovernmental transfers on growth, we use a panel of the ten West German states (excluding Berlin) covering the years 1975-2005. The sources and the definition of the data used in this paper are listed in Table A-4 in the online appendix. The information is complete in all years, i.e., the sample contains 300 observations.

The East German states are excluded for several reasons. First, pooling the East and West may mask structural heterogeneity between the two sets of states, making it difficult to pin down the mechanisms underlying the estimates. In West Germany, adverse growth effects of transfers may have been caused by governments' use of transfers to support declining industries. The situation in the East after reunification was extraordinary. Adverse growth effects of transfers in the East may have been caused by high consumption spending. However, transfers in the East may have been conducive for growth if they are used to fund public investments. For instance, due to the circumstances, a substantial fraction of transfers to East German states were used for public investment (Aufbau Ost).

Second, the East German states were only fully integrated into the German fiscal system in 1995. If the observations starting in 1995 are included, our instrument (reform of the horizontal equalization scheme in 1995) may pick up the effect of extending the sample. The instrument only displays meaningful variation for the West German states. Hence, identification with respect to our instrument is difficult for the East. We explore whether the results change when they are included as a robustness check.

\section{Empirical approach}

The relationship between transfer dependence and economic development can be modeled as follows:

$$
y_{i, t}=\alpha_{i}+\gamma_{t}+\beta \text { Transfer } \operatorname{ratio}_{i, t-1}+\mathbf{X}_{i, t} \delta+\epsilon_{i, t} .
$$


This empirical model states that growth in state $i$ and year $t$ is a function of the transfer ratio in the previous year, a set of additional control variables, and an error term. We estimate enhanced Barro-type growth regressions using panel data such that, by controlling for state fixed effects, our estimates are more robust to unobserved heterogeneity than pure cross section analyses (Mankiw et al., 1992; Islam, 1995).

The main variable of interest is the transfer ratio in the previous period $(t-1)$. The transfer ratio variable is defined in the baseline regressions as the share of horizontal and vertical transfer receipts in total state revenues. It indicates how reliant a state is on transfers. To study the longer term link, we test whether the transfer ratio in $t-2$ or $t-3$ or moving averages of the previous three years have an effect on growth in year $t$.

We use the growth rate of GDP per capita as the dependent variable $y$ in the baseline regressions. In robustness tests, however, we explore how transfer dependence relates to growth of GDP per worker and the growth rate of gross investments.

One possibility to identify the causal effect of transfers is to rely on a selection on observables approach. If we were able to control for all relevant determinants $\mathbf{X}$ of both transfer receipts and growth rates we could obtain an unbiased estimator for $\beta$. However, even with an extensive list of control variables a lurking danger of any selection of observables approach is that there remain unobserved variables that simultaneously determine transfers and economic growth. In addition, controlling for too many variables might lead to the "bad controls" problem (controlling for variables that are themselves affected by transfers, see Angrist and Pischke (2009)) or reduce statistical power. To account for possible omitted variable bias while retaining the ability to specify parsimonious models, we rely on an instrumental variables approach. To induce exogenous variation in transfer receipts, we exploit the reform of the transfer scheme in 1995.

As indicated in Section 2, the LFA transfer scheme was reformed in the aftermath of unification. One consequence of the reform was that the intensity of equalization was increased from 1995 onward. Net-recipient states, irrespective of whether they were located in West- or East-Germany, were supposed to receive ceteris paribus higher transfers 
while the net-paying states were expected to pay more. We therefore define a dummy variable that is 1 for all net-recipient states in any year after 1995 and use this dummy as an instrument for transfer receipts. Conditional on state and year fixed effects and certain control variables (see below), this dummy should be positively correlated with the transfer receipts of the net-recipient states.

For this instrument to be valid, the reform should indeed induce quasi-exogenous variation. This assumption is plausible given that it ultimately relies on the unexpected shock of German reunification. Specifically, the reform of the transfer system was necessitated by the need to include the East-German states into the system, i.e., an exogenous shock to the transfer system. In contrast, the next reform of the equalization scheme in 2005 was endogenous. It was enforced by the Federal Constitutional Court following a complaint by the net-paying states about the high transfer volumes.

Reverse causality - expected future growth rates in net-recipient states causing the reform of equalization - is unlikely to bias the estimates. The main reason why there may be reverse causality is that if states for whom it was known that they would have low growth rates in the post-1995 period were able to extract higher transfer commitments at the time of the negotiations (1991-1994). Yet, while policy-makers might have had expectations about future growth rates, any such concerns would have been relegated to second rank given the overarching need to integrate the Eastern states. In fact, for the Eastern states - those that did benefit most from the higher transfer volume - expectations about future growth rates in the early nineties were highly optimistic.

This view is corroborated by Bösinger (1999) who extensively analyzed the negotiations leading to the 1995 reform. Legally, Art. 7 of the Unification Treaty legislated the distribution of revenue in the German federation only until the end of 1994. Afterwards the new Länder should be fully integrated in the general system of fiscal equalization such that the reform was the result of unification and not of the previous shortcomings of the old fiscal equalization system. While the old system had five net-payers and five net-recipients, it was obvious that this relatively balanced system would definitely 
become asymmetric. The main interest of the states in the negotiations was to secure their revenue levels, and if possible to extend them. They thus mainly aimed at getting as much revenue as possible from the federal government. This distribution game was rather detached from the relative fiscal strength from the states to each other and therefore at best little influenced by their GDP per capita, not to speak of economic growth. Growth concerns did not determine the discussion.

The second reason why the post-reform dummy could be endogenous is related to the question whether a state is a net-recipient or a net-payer. Technically, the status of a state as a net-payer or net-recipient is an endogenous variable. It depends inter alia on ownsource tax revenues. However, states have no tax autonomy and therefore revenues should be largely exogenous. One concern is nevertheless that in the administrative system of Germany, states are responsible for the collection of taxes. It is possible that states devote less effort to tax collection in view of the transfer system (Baretti et al., 2002). Yet, there is a limit to possible under-collection as excessive and persistent manipulation will induce a political backlash. Moreover, for most states, tax effort cannot reasonably affect revenues to such an extent that the status during equalization changes. Even severe under-collection will not turn Baden-Württemberg to a net-recipient and no amount of tax effort will make a net-payer out of Berlin.

Another concern is that GDP per capita (i. e., the tax base) evolves endogenously. However, our argument is that the transfers a state receives mainly depend on the level of GDP per capita and not its growth rate. GDP per capita is effectively pre-determined as it is dependent on factors that the state government cannot affect in the short-run, e. g. agglomeration advantages, the presence of important industries, education levels of the working-age population, etc. While growth rates will affect transfers to some extent, the short-term variation in transfers due to differing growth rates is arguably much smaller than the variation due to differing GDP per capita levels. We therefore believe that it is defensible to treat the position of a state during fiscal equalization in a given year as exogenous to any contemporaneous policies in that state. There are realistically no 
policies available to state governments that would turn a state from a net-recipient to a net-payer in the short- or medium-term given its underlying economic fundamentals.

Based on these arguments, our first stage is specified as follows:

$$
\text { Transfer } \text { ratio }_{i, t-1}=\text { Post-1995 } \text { reform }_{i, t-1}+\alpha_{i}+\gamma_{t}+\delta \mathbf{X}_{i, t}+\nu_{i, t} \text {, }
$$

where the dependent variable is the transfer ratio of state $i$ in period $t$ and post-1995 reform is a dummy that is 1 if a state is a net-recipient in the same period. The other variables are defined as in the second stage model specified in Equation 4 .

One feature of our instrument is that it will induce exogenous and strong variation in transfer dependence only conditional on two control variables. First, state revenues per capita is an important control variable because transfers increase mechanically when revenues have been low in a given year. Second, state population is a necessary control variable given that transfers to a given state $i$ depend on relative population sizes, i. e., population in state $i$ and all other states. We therefore always include both variables in the vector $\mathbf{X}$. In addition, we include human capital in the model Mankiw et al., 1992). Barro (1999) shows that human capital is an important determinant of growth. We proxy how changes in human capital affect growth with the change in the share of high-skilled (individuals with degrees from applied universities (Fachhochschule) or research universities) in the workforce of a state.

As additional covariates, we include in all models (i) the lag of GDP per capita to control for convergence, (ii) the share of above 65 year old persons in the state population, (iii) the share of below 15 year old persons in the state population, (iv) debt per capita in the previous period. We always control for state and year fixed effects. 


\section{$5 \quad$ Results}

\subsection{Baseline results}

We first establish that the instrument is a significant predictor of transfer dependence by estimating the (first stage) model specified in Equation 5. Table 1 collects the results from estimating Equation 5. The models include state and year fixed effects. Model I includes the post-1995 dummy for the net-recipient states, in addition to state and year fixed effects and the time-varying control variables. The instrument relates to the transfer dependence variable as expected. After the reform in 1995, transfer dependence in net-receiving states was on average about 7.6 percentage points higher than before. The effect is similar but slightly higher if we use a three-year moving average of the share of transfers on total revenues as the dependent variable (model II).$^{6}$

Table 2 relates transfer dependence to growth by estimating Equation 4 while instrumenting the transfer dependence variable. In Model I, the post-1995 reform dummy is used to instrument the transfers in year $t-1$. The estimated effect of transfer dependence is negative and significant at the $10 \%$ level. Using the second (model II) or third (model III) lags of transfer dependence leaves the coefficient negative but smaller and insignificant. These results suggest that transfer dependence in the previous period has a negative effect on economic growth, while transfers two or three years ago have no effect. The coefficient on transfers paid or received in the three previous years (moving average) is in magnitude similar to the one in model I and insignificant.7

The Cragg-Donald weak identification F statistic is sufficiently large in all models. While no critical values have been tabulated for this statistic when the error term is

\footnotetext{
${ }^{6}$ The full results are reported in Table A-1 in the online appendix. The table shows the unexpected result that GDP per capita coefficient is positive. An explanation is that among the net-recipients, the city-states receive substantial transfers because their inhabitants are weighted by a factor of 1,35 during fiscal equalization ("Einwohnerveredlung"). Dropping the city states turns the coefficient negative and significant (results are available from the authors upon request).

${ }^{7}$ As for the first stage results, the full second stage results are available in Table A-2 in the online appendix. We also report in Table A-3 the reduced form results.
} 
non-i.i.d., a value of 4 is typically sufficient to rule out significant biases because of weak identification (Staiger and Stock, 1997; Clemens et al., 2011).

The TSLS models show that transfers are at best irrelevant for growth. According to some models, an increase in transfer dependence might even be harmful.

\subsection{Robustness}

We report additional regressions to establish the robustness of the baseline results. First, we explore whether the estimates are similar if we employ other proxies for economic growth than GDP per capita. In Table 3, we report regression results using the growth rate of GDP per worker and gross investments as dependent variables. Similar to the results on GDP per capita, the transfers in $t-1$ and the three-year moving averages have a significantly negative effect on the two proxies for growth.

In Table 4, we report results for two different samples. In Model I, we include all EastGerman States and Berlin. As mentioned above, the East-German States and Berlin received special treatment in the 1995 reform and received additional transfers to cope with the cost of reunification. Including the six states does not affect the results significantly. The estimated coefficient is of similar magnitude as the one excluding those states (significant at the $5 \%$ level). The weak-identification test statistic is large.

In Model II, we drop the three city states: Berlin, Bremen, and Hamburg. These states are treated differently from the regular states during fiscal equalization. In particular, their inhabitants were weighted by a factor of 1.35 when calculating the fiscal needs parameter. Consequently, the transfer receipts of other states might be particularly sensitive to developments in these three states. Dropping these states does not affect the results qualitatively: the estimated coefficient remains negative. In fact, the absolute value of the coefficient is larger than in the baseline regressions. 


\section{Transmission channels}

As the final step of the analysis, we explore possible transmission channels for the baseline estimates. As mentioned above, an increase in fiscal resources in principle allows states to invest in growth-enhancing policies. The results in the last section, however, indicate that transfers do not result in higher growth rates.

One reason why we observe a negative effect of transfers on economic growth might be that state governments use transfers to support declining industries. Traditionally, the economic wealth of Germany derived from its manufacturing sector. As in many early industrialized countries, however, this sector went into a persistent decline when global competition increased in the seventies. All German States were hit by this economic transformation. Their governments could essentially make two choices. They could ignore the decline of the manufacturing sector and the associated increase in unemployment rates and invest resources to prepare their state for the new services based economy. Alternatively, they could use their fiscal resources to slow down the decline of the manufacturing sector by subsidizing struggling firms. While such a policy can benefit state inhabitants in the short-run as it secures their jobs for the time being, it might hamper structural change and thus depress long-term growth (Feld et al., 2012).

To explore these issues, Table 5 relates transfers to the share of the services and manufacturing sectors in gross value added. Any attempt to use transfers to foster economic growth should be reflected in an increase in the importance of the services sector. Support of declining industries should be reflected in an increase of the manufacturing sector. We instrument the transfer ratio with the post-1995 reform dummy. We observe that transfers are negatively related to the share of the service sector and positively related to the share of the manufacturing sector. One explanation for the results is that state governments use transfers to stabilize the manufacturing sector, presumably by subsidizing struggling companies. Anecdotal evidence, e.g., from Saarland and Bremen, suggest that 
substantial resources were devoted to the subsidization of declining industries. However, we do not know for sure whether this is the reason for the observed link.

More direct evidence in support of this interpretation is provided in Table 6. In this table, we relate transfers to different state expenditure categories. The results suggest that transfers are not used to improve infrastructure or expand educational opportunities for state inhabitants: the transfer ratio is unrelated to state expenditures for categories such as transport and communications and education. On the other hand, transfers have a positive and strongly significant effect on expenditures for economic promotion. The category economic promotion encompasses many individual tasks, but an important one is indeed the provision of subsidies.

\section{Conclusion}

We study the effect of intergovernmental transfers on economic development based on the West German States. Germany offers an interesting context to explore the link between transfers and economic growth since its transfer system redistributes considerable resources between the states. Using a reform of the intergovernmental transfer scheme in 1995 for identification, we find that transfer reliance was at best irrelevant and possibly even harmful for economic growth. Further investigations provide some support for the idea that the reason why transfers may be harmful for economic development is that they allow state governments to support declining sectors.

The finding that transfers are irrelevant or even harmful for growth contradicts recent results for other countries. This contradiction leads to the question whether the results in this paper have external validity. Existing evidence that points to a positive effect of transfers on development originates mostly from developing and transition countries (Becker et al., 2010, 2012; Litschig, 2012). However, the transfer systems in more developed countries likely varies along a number of explicit and implicit dimensions from those studied in these papers. In line with this notion, it is plausible that the results from 
Germany carry over to developed countries such as Italy or Belgium - countries that are both industrialized and have large implicit or explicit interregional transfer flows. The results may also explain the contemporaneous under-development of the Mezziogiorno or the persistent transfer-dependence of the Walloon region.

An important limitation of our analysis is that the underlying assumptions of our instrumental variables approach are ultimately not testable. While, as argued above, the reform instrument is reasonable, further studies should investigate this question with different methodologies to establish the robustness of our results. Similarly, we acknowledge that the mechanisms through which transfers may affect growth must be investigated in more detail in future research before definite conclusions can be reached.

\section{References}

Angrist, J. D. and J.-S. Pischke (2009). Mostly harmless econometrics: an empiricist's companion. Princeton University Press.

Asatryan, Z. and L. Feld (2015). Revisiting the link between growth and federalism: A bayesian model averaging approach. Journal of Comparative Economics 43, $772-781$.

Baretti, C., B. Huber, and K. Lichtblau (2002). A tax on tax revenue. The incentive effects of equalizing transfers: evidence from Germany. International Tax and Public Finance 9(6), 631-649.

Barro, R. (1999). Determinants of economic growth: a cross-country empirical study. MIT Press.

Barro, R. and X. Sala-I-Martin (1991). Convergence across states and regions. Brookings Papers on Economic Activity 22, 107-181.

Baskaran, T., L. Feld, and J. Schnellenbach (2016). Fiscal federalism, decentralization and economic growth: A meta-analysis. Economic Inquiry 54, 1445 - 1463. 
Baskaran, T. and L. P. Feld (2013). Fiscal decentralization and economic growth in OECD countries: is there a relationship? Public Finance Review 41, 421-445.

Becker, S. O., P. H. Egger, and M. von Ehrlich (2010). Going NUTS: the effect of EU structural funds on regional performance. Journal of Public Economics 94, 578-590.

Becker, S. O., P. H. Egger, and M. von Ehrlich (2012). Absorptive capacity and the growth effects of regional transfers: a regression discontinuity design with heterogenous treatment effects. American Economic Journal: Economic Policy 5, 29-77.

Behnisch, A., T. Büttner, and D. Stegarescu (2002). Public sector centralization and productivity growth: Reviewing the German experience. ZEW Discussion Paper No. 02-03.

Berthold, N., S. Drews, and E. Thode (2001). Die Föderale Ordnung in Deutschland - Motor oder Bremse des Wirtschaftlichen Wachstums? University of Würzburg Discussion Paper No. 42.

Berthold, N. and H. Fricke (2005). Föderalismus und Wachstum - Eine vernachlässigte Beziehung. Mimeo (University of Würzburg).

Berthold, N. and H. Fricke (2007). Volkswirtschaftliche Auswirkungen der finanziellen Ausgleichssysteme in Deutschland. Mimeo (University of Würzburg).

Boldrin, M. and F. Canova (2001). Inequality and convergence in Europe's regions: reconsidering European regional policies. Economic Policy 16, 205-253.

Breidenbach, P., T. Mitze, and C. Schmidt (2016). Eu structural funds and regional income convergence - a sobering experience. CEPR Discussion Paper No. 11210.

Brollo, F., T. Nannicini, R. Perotti, and G. Tabellini (2010). The political resource curse. NBER Working Paper No. 15705.

Bösinger, R. (1999). Die Neuordnung des bundesstaatlichen Finanzausgleichs 1995. Peter Lang, Frankfurt et al. 
Büttner, T. (2002). Fiscal federalism and interstate risk sharing: empirical evidence from germany. Economics Letters 74(2), 195-202.

Bucovetsky, S. (1998). Federalism, equalization and risk aversion. Journal of Public Economics 67, 301-328.

Bucovetsky, S. and M. Smart (2006). The efficiency consequences of local revenue equalization: tax competition and tax distortions. Journal of Public Economic Theory 8, $119-144$.

Burchardi, K. B. and T. A. Hassan (2013). The economic impact of social ties: evidence from German reunification. Quarterly Journal of Economics 128, 1219-1271.

Burnside, C. and D. Dollar (2000). Aid, policies, and growth. American Economic Review 90, 847-868.

Caselli, F. and G. Michaels (2013). Do oil windfalls improve living standards? Evidence from Brazil. American Economic Journal: Applied Economics 5, 208-238.

Clemens, M. A., S. Radelet, R. R. Bhavnani, and S. Bazzi (2011). Counting chickens when they hatch: timing and the effects of growth on aid. Economic Journal 122, $590-617$.

Easterly, W. (2003). Can foreign aid buy growth? Journal of Economic Perspectives 17, $23-48$.

Feld, L. P., J. Schnellenbach, and T. Baskaran (2012). Creative destruction and fiscal institutions: a long-run case study of three regions. Journal of Evolutionary Economics 22, 563-583.

Fuchs-Schündeln, N. (2008). The response of household saving to the large shock of German reunification. American Ecnomic Review 98, 1798-1828. 
Fuchs-Schündeln, N. and M. Schündeln (2005). Precautionary savings and self-selection: evidence from German reunification experiment. Quarterly Journal of Economics 120, $1085-1120$.

Islam, N. (1995). Growth empirics: a panel data approach. Quarterly Journal of Economics 110, 1127-1170.

Kessler, A., N. Hansen, and C. Lessman (2011). Interregional redistribution and mobility in federations: a positive approach. Review of Economic Studies 78, 1345-1378.

Koetter, M. and M. Wedow (2013). Transfer payments without growth: evidence from German regions. International Journal of Urban and Regional Research 37.4, 14381455 .

Litschig, S. (2012). Financing local development: quasi-experimental evidence from municipalities in Brazil. Mimeo (Universitat Pompeu Fabra and Barcelona GSE).

Mankiw, N. G., D. Romer, and D. N. Weil (1992). A contribution to the empirics of economic growth. Quarterly Journal of Economics 10\%, 407-437.

Persson, T. and G. Tabellini (1996a). Federal fiscal constitutions: risk sharing and moral hazard. Econometrica 64(3), 623-646.

Persson, T. and G. Tabellini (1996b). Federal fiscal constitutions: risk sharing and redistribution. Journal of Political Economy 104(5), 979-1009.

Reinikka, R. and J. Svensson (2004). Local capture: evidence from a central government transfer program in Uganda. Quarterly Journal of Economics 199, 679-705.

Staiger, D. and J. H. Stock (1997). Instrumental variables regressions with weak instruments. Econometrica 65, 557-586.

Stansel, D. (2005). Local Decentralization and Local Economic Growth: A CrossSectional Examination of US Metropolitan Areas. Journal of Urban Economics 5\%, $55-72$. 
Thornton, J. (2007). Fiscal decentralization and economic growth reconsidered. Journal of Urban Economics 61(1), 64-70.

Xie, D., H. Zou, and H. Davoodi (1999). Fiscal decentralization and economic growth in the United States. Journal of Urban Economics 45, 228-239. 












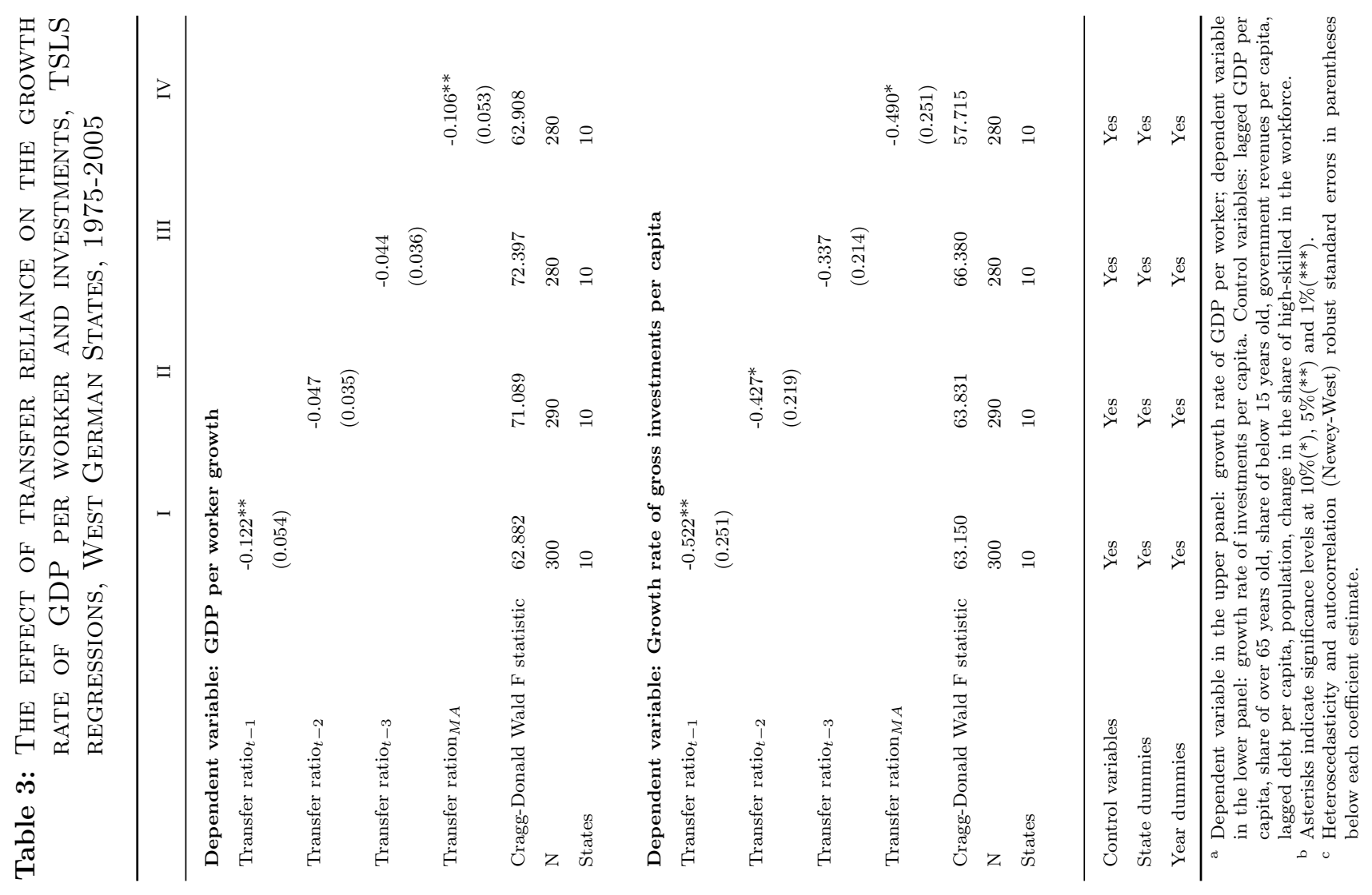














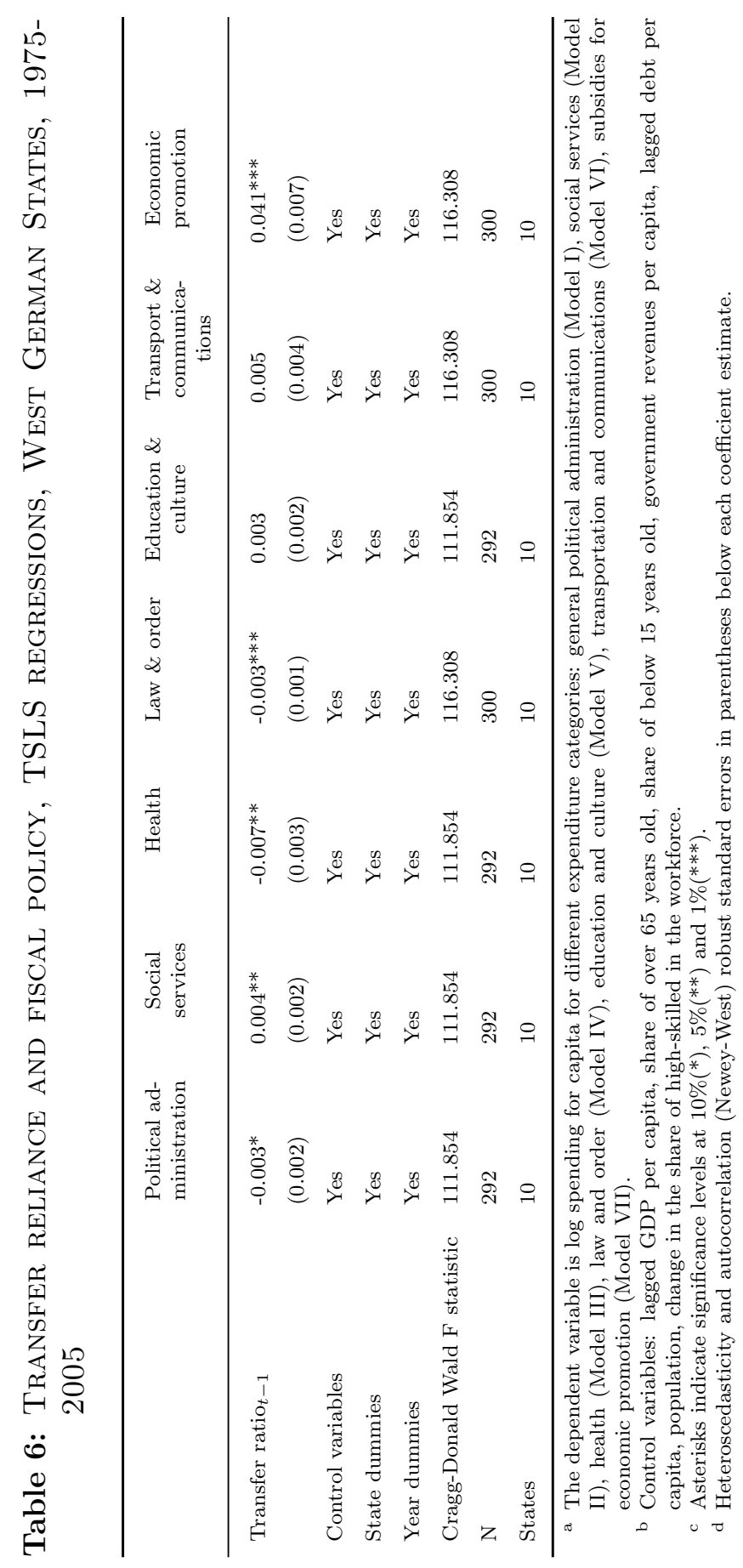




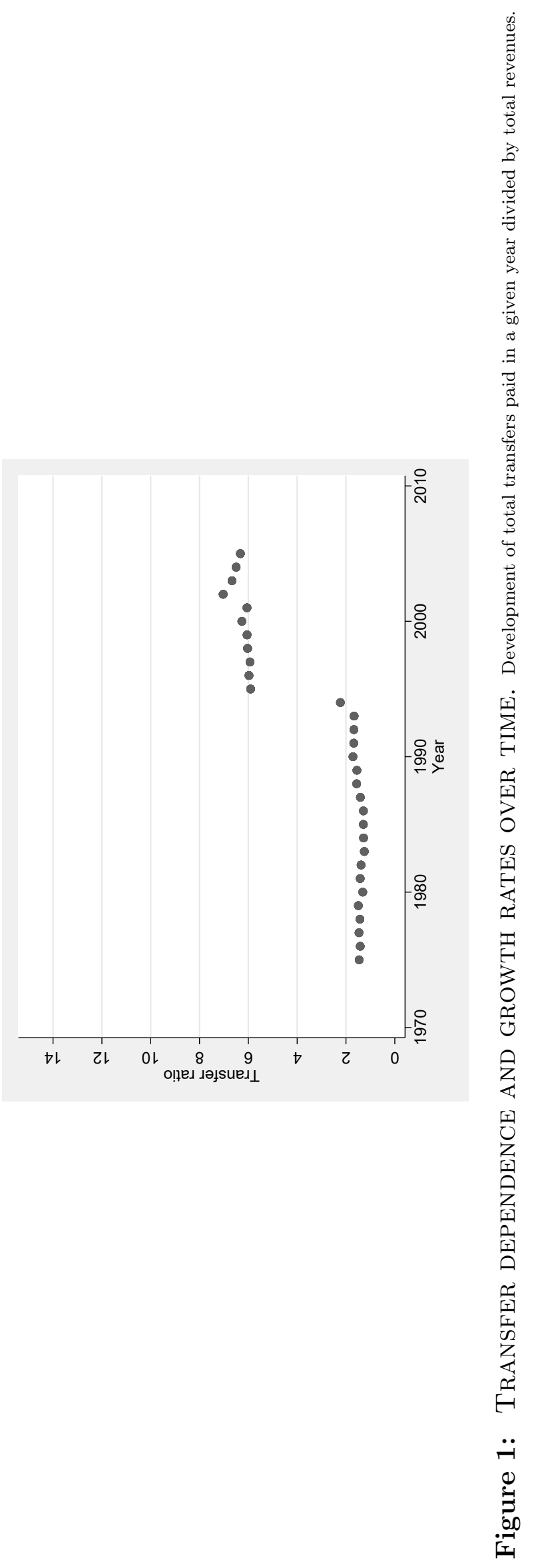

